\title{
STRUKTUR PARADIGMATIK ILMU-ILMU KEISLAMAN KLASIK: Dampaknya terhadap Pola Pikir, Sikap, dan Perilaku Keberagamaan
}

\author{
Ichwansyah Tampubolon \\ Sekolah Tinggi Agama Islam Negeri Padangsidimpuan \\ Jl. H.T Rizal Nurdin, Km. 4,5 Padangsidimpuan, 22733 \\ e-mail: ichwansyah.tampubolon@yahoo.com
}

\begin{abstract}
Abstrak: Artikel ini mengkaji struktur paradigma Ilmu-ilmu keislaman klasik yang mendominasi diskursus intelektualisme Islam di dunia Islam Sunni. Secara epistemologis, dalam upaya meletakkan dasar-dasar keilmuannya, otoritas teks-teks kewahyuan dan pola pikir ulama salaf bercorak analogis (qiyâs), konsensus (ijmâ'), dan intuitif (dzauqî) sangat mendominasi model pendekatan daripada penalaran akal secara filosofis. Secara ontologis, Ilmu Kalam, Fikih/Usul Fikih dan Ilmu Tasawuf lebih berorientasi pada transformasi nilai-nilai keislaman secara moral spiritual daripada upaya pemenuhan kebutuhan hidup dan peningkatan kesejahteraan hidup secara duniawi. Dalam pada itu, secara umum, pola pikir keilmuan Islam kasik itu berpengaruh terhadap pembentukan corak pemahaman, sikap dan perilaku umat beragama menjadi bersifat eksklusif, kaku, fanatik, tidak kreatif, dan anarkis.
\end{abstract}

\begin{abstract}
Paradigmatic Structure of Classical Islamic Sciences, its Impact on Mindset, Attitude and Religious Experience. The aims of this article is to study the paradigmatic structure of the classical Islamic knowledge which had dominated the discources of Islamic intellectualism in the world of Sunni Muslim. Epistemologically, in order to contruct the principles of classical Islamic knowledge, the revealed textsand the thought patterns of ulama Salaf such as analogy (qiyâs), consensus (ijmâ'), and intuitive (dzauqî) had dominated. Axiologically, the purpose of classical Islamic knowlegde is more oriented to transform Islamic values and defense of "religious" in order to gain the here after happiness, howeverthe aspects of socially realistic "secular" life tends to be periferal.In general, both textual-bayânî and 'irfâni paradigm which till now have been established in the world of Islamic education had affected the mindset, attitude, and conduct of Ummah's religiosity in order to respon the problems, opportunities, and challenges of modernity and globalization.
\end{abstract}

Kata Kunci: sejarah Islam, tekstual-bayânî, irfânî, intelektualisme Islam klasik 


\section{Pendahuluan}

Ilmu-ilmu Keislaman klasik merupakan warisan (turâts) peradaban Islam yang ditransmisikan dan dikaji ulang secara intensif dan simultan oleh para cendekiawan Muslim dari masa ke masa sehingga menciptakan tautan mata rantai kebudayaan yang hidup (a living culture), khususnya di dunia Islam. Keterkaitan mata rantai intelektualisme itu pada gilirannya membentuk kebudayaan teks (hadharah al-nashsh) sebagaimana terwujud setidak-tidaknya dalam empat bidang ilmu, yaitu: Kalam, Fikih/Ushul Fikih, Falsafah, dan Tasawuf ${ }^{1}$ yang dirancang dan disusun pada era klasik-skolastik Islam, sekitar abad ke10 hingga abad ke-12. ${ }^{2}$ Dalam pandangan M. Abed al-Jabiri, keempat bidang Ilmu-ilmu Keislaman klasik itu memiliki karakteristik paradigmatik masing-masing, yaitu bercorak tekstual-bayânî (Kalam, Fikih/Ushul Fikih), burhânî (Falsafah), dan irfânî (Tasawuf). ${ }^{3}$

Namun, dari keempat disiplin ilmu itu, sejak berakhirnya era Ibn Rusyd (w. 1198) hingga kini hanya tiga bidang ilmu yang dilestarikan di dunia Islam Sunni, mencakup Kalam, Fikih/Ushul Fikih, dan Tasawuf, sedangkan Ilmu Falsafah dikucilkan dari kancah pengkajian Ilmu-ilmu keislaman. Berbeda halnya dengan dunia Islam Sunni, dunia Islam Syi'ah tetap menghidupkan dan mengembangkan tradisi keilmuan rasional-filosofis dengan variasi corak pemikirannya yang sangat khas dan beragam sehingga mampu melahirkan beberapa filsuf terkemuka di hampir setiap abad. Jadi, sekalipun al-Ghazâlî (w. 1111) telah berupaya meredupkan lampu filsafat di dunia Islam Sunni, namun tidak sampai satu abad setelah serangan al-Ghazâlî itu, tradisi dan filsafat Ibn Sînâ (w. 1037) telah dihidupkan kembali dan dikembangkan dengan modifikasi iluminatif oleh Syihâb al-Dîn Suhrawardî al-Maqtûl (w. 1191) serta dipertahankan dan dikembangkan kemudian oleh Quthb al-Dîn al-Syîrâzî (w.1311). Demikian juga serangan terhadap filsafat Ibn Sînâ oleh Fakhr al-Dîn al-Râzî (w. 1209) telah dijawab oleh Nashir al-Dîn al-Thûsî (1274), seorang filsuf dan astronom Syi'ah yang terkenal. Pemikiran filsafat juga dikembangkan oleh generasi intelektual zaman berikutnya yang tergabung dalam mazhab Isfahan, seperti Mir Damad atau Muhammad Baqir Astarabadi (w. 1632) dan muridnya Mullâ Shadrâ atau Shadr al-Dîn Syîrâzî (w. 1641), Mulla Abd al-Razzâq Lahîîi (w. 1661) dan Mulla Faidz Kâsyânî (w. 1091), dan lain-lain hingga zaman kontemporer, misalnya Murtadha Mutahhari (1979), Muhammad Thabathaba`i (1981), Mahdi Ha iri Yazdi, M. Taqi Misbah Yazdi, Shadr al-Baqir, dan Seyyed Hossein Nasr. Di tangan para filsuf inilah tradisi filsafat Islam dan ilmu-ilmu rasional lainnya dipelihara, diolah, dan dikembangkan secara sistematik sehingga mencapai tingkat kecanggihan

${ }^{1}$ Nurcholish Madjid, Islam Doktrin dan Peradaban, cet. 4(Jakarta: Paramadina, 2000), h. 201-252. M. Amin Abdullah, Islamic Studies di Perguruan Tinggi (Yogyakarta: Pustaka Pelajar), h. 142-143. Bandingkan, Falur Rahman, Islam, terj. Ahsin Muhammad (Bandung: Penerbit Pustaka, 1997), h. 275. M. Abed al-Jabiri, Post-Tradisionalisme Islam (Yogyakarta: LkiS, 2000), h. xxxix.

${ }^{2}$ M. Arkoun, Al-Islâm: al-Akhlâq wa al-Siyâsah, terj. Hashim Shaleh (Bairut: Markaz al-Inma' al-Qaumi, 1990).

${ }^{3}$ M. Abed al-Jabiri, Takwîn al-Aql al-Arabî (Bairut: Markaz Dirâsât al-Wihdah al-`Arabiyyah, 1989). 
tertinggi. Konservasi dan pengembangan tradisi filosofis dan ilmiah inilah yang memungkinkan para filsuf Syi‘ah mampu membangun sistem-sistem filosofis besar, kokoh, dan independen, juga mampu menyusun metodologi filosofis yang cocok dengan semangat pencarian filosofis dan sesuai dengan perkembangan zaman. Sistem-sistem filosofis ini pada gilirannya memungkinkan mereka untuk mengadakan respons, dialog, dan bahkan koreksi yang konstruktif terhadap rekan filosofisnya dari dunia Barat. Thabathaba'i dan diteruskan oleh muridnya Murtadha Mutahhari berhasil dengan baik dalam berdialog atau mengkritisi dengan jitu paham Marxisme yang pernah dikembangkan di Iran oleh Partai Tudeh dan sangat berpengaruh terhadap kaum intelektual muda Iran. ${ }^{4}$

Di satu sisi, kekayaan khazanah intelektualisme Islam klasik itu membuktikan betapa peradaban Islam memiliki vitalitas, kreativitas, dan kemampuan adaptabilitas secara inklusif terhadap berbagai budaya dari segala penjuru dunia. Di sisi lain, khazanah keilmuan itu sekaligus menjadi warisan (turâs) yang sangat berharga dan penting kedudukannya bagi pembangunan peradaban umat manusia zaman kekinian dan yang akan datang. Namun, seiring dengan massifnya penyebaran Ilmu Kalam, Fikih/Ushul Fikih, dan Tasawuf di dunia Islam Sunni, khususnya, secara sadar atau tidak, tersebar pulalah pola pikir bercorak tekstualbayânî dan "irfânî di kalangan mayoritas umat yang pada gilirannya memengaruhi dan mendominasi cara pandang mereka dalam memahami berbagai persoalan kehidupan. Hal ini pada gilirannya ditengarai turut memengaruhi dan membentuk sikap dan perilaku keberagamaan umat Islam dewasa ini. Pada zaman kontemporer ini, sebagian besar umat Islam cenderung reaktif berhubungan dengan upaya menjawab kompleksitas persoalan yang muncul dan berkembang di zaman kekinian. ${ }^{5}$

\section{Paradigma Kalam, Falsafah, Fikih, dan Tasawuf}

\section{Paradigma}

Paradigma, secara etimologis, berarti matriks, disipliner, model/pola pikir, pandangan dunia (world view), konstelasi teori, pertanyaan, pendekatan, prosedur, dan tema pemikiran. Sementara secara terminologis, setidaknya terdapat dua puluh satu pengertian paradigma, di antaranya adalah seperangkat asumsi, tersurat maupun tersirat, yang berfungi sebagai

${ }^{4}$ Setelah abad ke-7H/13M tradisi filsafat Islam masih tumbuh dan berkembang, khususnya di dunia Islam Syi'ah, di antaranya Filsafat Illuminatif (Isyrâqiyyah) yang digagas oleh Suhrawardî al-Maqtûl dan teosofi al- $\underline{H}$ ikmah al-Muta âliyah yang digagas oleh Mullâ Shadrâ, Seyyed Hossein Nasr, "Filsafat Hikmah Suhrawardî," dalam Jurnal Ulum al-Qur'an, Edisi ke-3/VII/1997, h. 52. Mulyadhi Kartanegara, Mengislamkan Nalar: Sebuah Respons terhadap Modernitas (Jakarta: Penerbit Erlangga, 2007), h. 30-32.

${ }^{5}$ Bandingkan dengan Ismail Raji al-Faruqi, "Islamization of Knowledge: Problems, Principles and Prospective," dalamThe International Institute of Islamic Thought, Islam: Source and Purpose of Knowledge (Herndon, Virginia, U.S.A.: IIIT, 1988), h. 15-63, terutama h. 18-19. 
dasar bagi gagasan-gagasan ilmiah, ${ }^{6}$ model-model fundamental atau kerangka pemahaman yang digunakan untuk mengatur suatu observasi dan penaralan, ${ }^{7}$ dan seperangkat asumsi metafisis, ontologis, epistemologis, teoretis, hukum-hukum, teknik-teknik aplikasi, dan sistem nilai yang dianut oleh suatu komunitas ilmiah sebagai kerangka konseptual untuk memahami dan memaknai fenomena-fenomema eksperimental maupun realitas sosial dalam kerangka pemahaman (frame of reference) yang sama, sehingga mereka dapat melangsungkan komunikasi antara satu dengan lainnya. ${ }^{8}$

\section{Postulat}

Postulat adalah kebenaran-kebenaran atau proposisi yang tidak dibuktikan oleh ilmu yang bersangkutan, akan tetapi dipinjam dari ilmu lain, seperti metafisika. Metafisika adalah ilmu tentang prinsip-prinsip pertama berkenaan dengan hal-hal atau entitas-entitas yang berada di belakang/di atas dunia fisik ( $m a ̂$ ba'd al-thabî‘ah/mâ fawq al-thabî́ah), meliputi Tuhan sebagai sumber dari segala yang ada, konsep-konsep umum tentang wujud, kesatuan, jenis-jenis, aksiden-aksiden, alam akhirat, alam spiritual, dan entitas-entitas immaterial, di antaranya akal, jiwa, dan malaikat. Metafisika bertugas menguji, membuktikan kebenarankebenaran postulat dan menjadi dasar bagi hal-hal umum yang diperlukan oleh semua ilmu, termasuk di bidang etika. ${ }^{9}$

Postulat-postulat keilmuan di bidang Kalam, Fikih, dan Tasawuf, khususnya didasarkan atas informasi kewahyuan sebagaimana yang terdapat dalam al-Qur'an dan Hadis. Postulatpostulat ketiga ilmu itu bersumber dari pengetahuan ilahiah yang disampaikan secara verbal (al-âyât al-kitâbiyyah/al-qauliyah) kepada umat manusia melalui risalah kenabian. Sedangkan, filsafat Islam postulat-postulatnya berasal dari penalaran akal yang kemudian dilegitimasi melalui dalil-dalil kewahyuan. Ringkasnya, pada umumnya postulat-postulat intelektualisme Islam klasik itu bersifat theistic/fedeistic subjectivism.

\section{Ontologi}

Secara ontologis, Ilmu Kalam memfokuskan kajiannya pada aspek ketuhanan (teologis) dan berbagai dimensi yang berhubungan dengannya misalnya Zat Tuhan, sifat-sifat Tuhan,

${ }^{6}$ Bernard S. Philips, Social Research, Strategy and Tactics (New York: Macmillan, 1971), h. 44.

${ }^{7}$ Earl Babbie, The Practice of Social Research (Belmont: Wadsworth, 2001), h. 42.

${ }^{8}$ T. Mautner (ed.), Dictionary of Philosophy (London: Pinguin Books, 1996), h. 408. Bandingkan, Thomas Kuhn, The Structures of Scientific Revolution (Chicago: The University of Chicago Press, 1970).

${ }^{9}$ Arthur Burts, The Metaphysical Foundation of Modern Science (New York: Doubleday Anchor Books, 1954). Charles Genequand, "Metaphysics," dalam Seyyed Hossein Nasr, History of Islamic Philosophy (London and New York: Routledge, 1996), h. 783-801, terutama h. 784-785. Mulyadhi Kartanegara, Nalar Religius: Memahami Hakikat Tuhan, Alam, dan Manusia (Jakarta: Penerbit Erlangga, 2007), h. 52-54. 
perbuatan Tuhan, makhluk-makhluk gaib, iman, takdir, perbuatan manusia, dosa, pahala, unsur-unsur eskatologis dan kepemimpinan. Ilmu Falsafah memusatkan perhatiannya pada persoalan-persoalan metafisik atau hal-hal yang bersifat perenungan tentang segala wujud secara radikal, kritis, rasional, komprehensif, dan universal. Ilmu Fikih memberikan perhatian utama terhadap sistem dan tata cara peribadatan secara formal kepada Tuhan, seperti salat, zakat, puasa, haji, dan juga mencakup hukum Islam, baik secara perdata maupun pidana, hubungan antarsesama manusia, seperti jual beli, wakaf, perkawinan, hubungan sosial-politik, dan sebagainya. Oleh karena itu, Ilmu Fikih lebih berorientasi eksoterik, mengenai hal-hal keagamaan yang bersifat lahiriah guna membangun tindakan praktis. Sementara Ilmu Fikih/Ushul Fikih menginferensi nilai-nilai yurisprudensial berdasarkan dalil-dalil kewahyuan.Ilmu Tasawuf memberikan perhatian khusus terhadap aspek kejiwaan-spritualistik. Ia lebih menekankan aspek esoterik atau kedalaman spiritualitas batiniah pengalaman keberagamaan Islam. Ilmu Tasawuf membidangi segi-segi penghayatan dan pengalaman keagamaan yang lebih bersifat pribadi, sehingga titik tekan orientasinya pun bercorak ruhaniah.

\section{Epistemologi}

Secara epistemologis, Ilmu Kalam dan Ilmu Fikih/Ushul Fikih menggunakan model penafsiran dan pemahaman secara analogis (qiyâs) dalam membahas berbagai ajaran dasar kewahyuan, khususnya persoalan-persoalan akidah dan syariah. Argumentasi-argumentasinya lebih banyak didasarkan pada teks-teks keagamaan daripada premis-premis logis yang ada di balik teks. Jadi, argumentasi kalam dan Fikih sangat erat kaitannya dengan dalil-dalil al-Qur'an dan hadis daripada argumentasi rasio. Kalaupun dalam hal ini digunakan kemampuan akal, maka hal itu lebih dimaknai sebagai penalaran analogis dengan didominasi oleh logika bahasa (lughawiyyah).Dalam analogi kebahasaan, kata asal (al-ashl) diposisikan sebagai rujukan atau acuan guna melahirkan kata baru/"cabang" (al-far') yang "sebenarnya tidak ada" secara faktual. Kedudukan kata baru/"cabang" (al-far ') yang diperoleh hanyalah sebagai hipotesis teoretis, bukan sebagai sebuah data induktif atau tidak berasal dari pengalaman empirik. Karena itu, kata baru/"cabang" (al-far ') yang dihasilkan dari metode analogi itu merupakan suatu "kemungkinan" (al-mumkin), ia mungkin diadakan selama terdapat suatu kata asal (al-asl) yang menjadi rujukannya. ${ }^{10}$

Demikian pula halnya berkenaan dengan lafaz dan makna (al-lafzh wa al-ma'nâ). Teks terbentuk dari kata-kata yang memiliki lafaz dan makna tertentu, bersifat umum ('âmm) maupun khusus (khâshsh), memiliki banyak makna (musytarak), bermakna hakiki (haqîqû) kiasan (majâzzî), perumpamaan (mutasyâbih), tertentu (mulkkam), tampak nyata (zhâhir), tersembunyi (khâfi) dan menyeluruh/global (mujmal). Hubungan antara lafal (teks) dan makna (isi) merupakan satu kesatuan yang tidak terpisahkan secara monistik,

\footnotetext{
${ }^{10}$ Al-Jabiri, Post-Tradisionalism, h. 67.
} 
sehingga tidak ada kemungkinan perbedaan pendapat dalam memahami teks. Sebab, teks dengan maknanya merupakan satu kesatuan. ${ }^{11}$

Sementara itu, dalam hal ini penggunaan akal sebagaimana mestinya dicurigai dan dipinggirkan oleh karena dianggap dapat menjauhkan teks dari kebenaran maksud yang dikandungnya. Konsekuensinya, akal tidak difungsikan, misalnya,sebagai alat untuk menganalisis sesuatu secara kritis-kategoris, misalnya dari sudut sebab-akibat (idrâk al-sabab wa al-musabbab), esensi, substansi, manfaat, ruang, waktu, kuantitas, kualitas, genus dan korelasi. Wilayah kerja akal dibatasi sedemikian rupa dan peranannya dialihkan menjadi pengekang dan pengatur hawa nafsu, sebagai alat untuk membenarkan (fungsi justifikatif), mengulang-ulang (fungsi repetitif) guna mengukuhkan kebenaran teks. Potensi akal dibatasi hanya pada tataran "pengambilan kesimpulan berdasarkan lafaz atau bahasa teks atau melalui metode analogi (qiyâs). Artinya, penarikan kesimpulannya cenderung mengutamakan metode istintâjiyyah ${ }^{12}$ yang lebih berorientasi pada pengambilan intisari atau hikmah dari dalil-dalil keagamaan secara tekstual.

Dalam Ilmu Fikih, misalnya, penggunaan metode analogi (qiyâs) sering menjadi primadona dalam proses penentuan keputusan hukum (istinbâth al-hrukm). Dalam konteks ini, para ahli Fikih (fuqahâ') berupaya menganalogisasi hal-hal yang belum ada hukumnya dengan sesuatu yang sudah ditetapkan status hukumnya oleh teks/nashsh (qiyâs alghaib 'alâ syâhid). Imam Syâfi'î (w. 204H) sangat besar peranannya membakukan cara berpikir secara analogis ini, terutama menyangkut hubungan antara bentuk formal lafziyah dengan makna, dan antara bahasa dengan teks al-Qur'an. Imam al-Syâfiîi sering diposisikan sebagai perumus "nalar Islam atau nalar Arab". Di tangan Imam al-Syâfîî-lah hukumhukum bahasa Arab dijadikan acuan untuk menafsirkan teks-teks suci dengan menggunakan metode qiyâs. Atas dasar itu, satu-satunya metode penalaran yang digunakan untuk menarik kesimpulan tentang suatu kasus baru (al-far') adalah metode analogi (qiyâs), di mana nashsh dijadikan sebagai sumber rujukan/asal (al-asl). Metode analogi seperti ini lazim disebut dengan istilah qiyâs al-illah, yaitu suatu metode yang menganalogisasi suatu entitas yang lain (yang belum ada hukumnya) dengan suatu entitas yang tercantum di dalam teks atas dasar kesamaan sifat yang dimilikinya.

Hal serupa juga terjadi di bidang Ilmu Kalam sebagaimana dikukuhkan oleh al-Asy'ari (w. 324 H). Dalam hal ini, Ilmu Kalam menggunakan analogi berdasarkan argumentasi dialektik-tekstual (qiyâs al-dalâlah) dengan mengacu pada model pola pikir Stoik dan bukan lewat silogisme atau premis-premis logika (mantiq) sebagaimana yang dikembangkan oleh Aristoteles atau Plato. ${ }^{13}$ Artinya, di bidang kalam, sebagaimana yang digunakan oleh

${ }^{11}$ Burhan Nurgiantoro, Teori Pengkajian Fiksi (Yogyakarta: Gadjah Mada University Press, 1995), h. 282.

${ }^{12}$ Al-Jabiri, Post-Tradisionlism, h. xii.

${ }^{13}$ Josep Van Ess, "The Logical Structure of Islamic Theology," dalam Issa J Boullata, (ed.), 
generasi awal mereka, analogisasi dunia riil terhadap dunia abstrak (istidlâl bi al-syâhid 'alâ al-ghaib). ${ }^{14}$ Dalam hal ini, penalaran berangkat dari sesuatu yang nyata (dunia riil/ empirik) untuk mengukuhkan yang gaib (seperti masalah-masalah metafisik, keimanan dan eskatologis). Metode ini digunakan oleh al-Asy'ari dalam melahirkan argumen-argumen tentang masalah-masalah ketuhanan yang sebenarnya juga merupakan kelanjutan dari argumen serupa yang berlaku di kalangan Mu'tazilah. Di tangan Mu'tazilah inilah persoalanpersoalan kalam terkait erat dengan metode-metode yang berlaku dalam bahasa, seperti qiyâs. Mereka mengunakan al-Qur'an, akal (qiyâs), dan ijma' sebagai basis epistemologisnya. Sebab, bagi mereka fungsi akal hanya "mengembalikan satu hukum cabang ke hukum asal" ${ }^{15}$

Penalaran analogis melahirkan argumentasi bertipe dialektik (jadâliyyah). Tujuannya adalah untuk mempertahankan kebenaran teks secara dogmatik-apologetik. Tolok ukur kebenaran suatu kesimpulan dari sebuah penalaran analogis adalah kesamaan atau kedekatan realitas empirik dengan nash. Semakin dekat suatu kesimpulan dengan nash, semakin valid kebenaran kesimpulan itu dan sebaliknya. Oleh karena sangat terkait dan tergantung kepada nash, kesimpulan yang diambilnya tentang sesuatu pun bersifat terpisah-pisah secara atomistik (infisâl) tanpa mengkaitkannya dengan faktor-faktor atau unsur-unsur lain yang mengitarinya secara kontekstual, misalnya dari sudut ideologis, sosiologis, kultural, politik, dan lain-lain. Semua boleh dijadikan sebagai dasar penyimpulan (tajwîz) asal hal itu terwakili di dalam nash, tanpa mempertimbangkan sisi rasionalitas berdasarkan hukum sebab-akibat.

Pola pikir tekstual-bayânî, dalam tataran tertentu, memiliki kemiripan dengan pola pikir deduktif Plato. Menurut Plato, segala sesuatu yang dapat diketahui oleh manusia berasal dari "ide-ide asal" (innead ideas), yaitu ide-ide yang tertanam dan melekat dalam diri manusia secara intrinsik-kodrati sejak awal mulanya. Manusia memiliki ide-ide bawaan yang sudah ada dalam dirinya sejak sebelum ia dilahirkan. Manusia tinggal mengingat kembali (recollection) ide-ide bawaan yang melekat begitu rupa dalam keberadaannya. ${ }^{16}$ Sedangkan perbedaannya, jika pola pikir deduktif model Plato didasarkan atas kemampuan intrinsik manusia, maka pola pikir deduktif model tekstual-bayânî didasarkan atas premispremis kitab suci secara tekstual. Artinya, pola pikir tekstual-bayânî semacam islamisasi pola pikir deduktif model Plato yang didasarkan atas ide-ide bawaan yang dimiliki oleh manusia secara intrinsik, diganti dengan pola pikir bayânî yang berpangkal atau berdasarkan pada teks kewahyuan. Konsekuensinya, pola pikir logika deduktif model Plato dapat dikritik dan dipertanyakan ulang oleh pola pikir manusia yang datang belakangan tanpa rasa takut

Anthology of Islamic Studies (Montreal Canada: Mc. Gill and Indonesia IAIN Development Project, 1992).

${ }^{14}$ Al-Jabiri, Post-Tradisionalism, h. 89.

${ }^{15}$ Ibid., h. xlii.

${ }^{16}$ Edith Hamilton dan Huntington Cairns (ed.), Plato: The Collected Dialogues (USA: Princeton University Press, 1961). 
dan segan, maka pola pikir deduktif keagamaan (Kalam dan Ushul Fikih) nyaris tidak boleh dipertanyakan ulang, dikritik, ditinjau atau ditelaah ulang. Hal ini semata-mata karena bahan dasar deduksi yang digunakan adalah ayat-ayat al-Qur'an dan hadis-hadis Nabi, sehingga produk rumusan pemikiran kalam pada umumnya telah dikunci rapat, tertutup, tidak dapat dikurangai atau diubah. ${ }^{17}$

Kemudian daripada itu, berbeda dengan pola pikir textual-bayânî di bidang Ilmu Kalam dan Ilmu Fikih, di bidang Ilmu Falsafah digunakan penalaran akal (logika) secara rasional dalam membahas dan menganalisis persoalan-persoalan yang dikajinya. Ilmu Falsafah diposisikan sebagai alat intelektualisme yang menanamkan kebiasaan dan melatih akal pikiran untuk bersikap kritis-analitis dan mampu melahirkan ide-ide segar yang sangat dibutuhkan untuk pengembangan filsafat itu sendiri maupun untuk pengembangan disiplin-disiplin keilmuan yang lain, tidak terkecuali berkaitan dengan persoalan-persoalan keagamaan dan teologis. ${ }^{18}$ Falsafah lebih memfokuskan tekanan pembahasannya pada premis-premis logis yang ada di balik teks. Falsafah lebih tertuju perhatiannya pada upaya pencarian makna, substansi, dan esensi pesan dalam teks-teks melalui penalaran logis.

Selanjutnya, Ilmu Tasawuf mengedepankan intuisi/kemampuan rasa (qalb). Di satu sisi, ia muncul sebagai reaksi terhadap menyatupadunya pola pikir Kalam dan Fikih yang dianggap terlalu kering dan formal. Di sisi lain, ia muncul sebagai upaya mengkritisi pemikiran filsafat yang dianggap terlalu mementingkan akal dan menepikan hati (qalb) dan rasa (dzauq). ${ }^{19}$

Dalam pandangan M. Abid al-Jabiri, keempat disiplin ilmu keislaman klasik ini, khususnya Ilmu Kalam, Ilmu Ushul Fikih, dan Ilmu Fikih, tidak saja terkait dengan teksteks keagamaan (ayat-ayat al-Qur'an dan teks-teks hadis), bahkan seringkali sampai ke pola pikir ulama salaf dalam bentuk konsensus (ijmâ') dan analogi (qiyâs) sebagaimana dibakukan dalam kaidah-kaidah metodologi Ushul Fikih klasik. Dalam pada itu, pola pikir ilmu-ilmu keislaman klasik juga sangat dipengaruhi oleh hukum-hukum bahasa Arab, terutama Ilmu Nahw/Ilmu Gramatika dan Ilmu Balâghah/Stilistika. Konsekuensinya, pola pikir epistemologi bahasa Arab (lughawiyyah) juga yang sangat dipengaruhi oleh kultur Arab (Badui) itu mengarahkan segenap mekanisme dan prosedur epistemologi ilmu-ilmu keislaman klasik. Ironisnya, menurut al-Jabiri, semenjak kodifikasi (tadwîn) bahasa Arab dilakukan oleh para ahli bahasa Arab, di antaranya: Abu Amr ibn al-A'lâ (w. 154 H), Hammad al-Râwiyah (w. 155 H), dan Khalil ibn Ahmad al-Farahidi (w. 170 H), ruang lingkup "dunia” bahasa Arab telah mengalami penyempitan. Oleh karena dalam pen-tadwîn-an bahasa Arab mereka mengambil bahan-bahan materialnya terbatas dari kalangan Arab Badui,

${ }^{17}$ Arkoun, Al-Islâm, h. 172-172.

${ }^{18}$ Fazlur Rahman, Islam and Modernity: Transformation of an Intellectual Tradition (Chicago and London: The University of Chicago Press, 1982), h. 157-158.

${ }^{19}$ M. Amin Abdullah, Islamic Studies di Perguruan Tinggi (Yogyakarta: Pustaka Pelajar, 2006), h. 142-143. 
bukan dari komunitas penutur bahasa Arab lainnya. Padahal, masyarakat Arab Badui hidup dalam dunia yang sangat terbatas ruang lingkupnya. Kehidupan mereka masih sangat sederhana, primitif, nomaden, pedesaan (Badui), kasar, tertutup, dan inderawi. Atas dasar itu pula, al-Jabiri berkesimpulan bahwa kaum Arab Badui lah yang sebenarnya pencipta "dunia" orang Arab yang kaya dengan kata-kata, ungkapan, persepsi, dan imajinasi dan bahkan juga pada level pikiran dan perasaan. Padahal dunia mereka sangat terbatas, sempit, kering, dan miskin. Keadaannya mirip dengan dunia yang dipantulkan oleh bahasa Arab pada masa jahiliyyah, masa prasejarah bangsa Arab, ${ }^{20}$ sehingga ruang lingkup bahasa Arab secara tidak disadari sesungguhnya telah mengalami penyempitan.

\section{Aksiologi}

Khazanah intelektualisme Islam klasik sebagaimana yang ditransmisikan atau diwariskan secara turun-temurun itu sesungguhnya merupakan teori-teori keilmuan yang dirumuskan dan disistematisasi ${ }^{21}$ oleh manusia (termasuk di dalamnya Nabi, sahabat, fuqahâ', ushûliyyûn, failasûf). Oleh karena itu, faktor-faktor yang mengitari kehidupan mereka, seperti keadaan psikis/intelektual, tempat, waktu, kepentingan dan perubahan sosial, politik, ekonomi dan budaya turut memberi warna bagi rumusan-rumusan keilmuan yang mereka hasilkan. Konsekuensinya, tidak ada jaminan immunitas ilmu-ilmu keislaman dari unsur campur tangan "kepentingan" manusia di dalamnya.

Namun, masyarakat Muslim pada umumnya tidak jarang menerimanya secara dogmatik tanpa kritik sama sekali. Bahkan, di antara komunitas Muslim ada yang memosisikannya sebagai "ideologi keagamaan" bahwa khazanah keislaman yang diwariskan oleh para ulama itu memiliki kesempurnaan dan tidak dapat diganggu gugat (ghayru qâbilin li taghyîr wa li al-niqâs) layaknya sebagai doktrin, dogma atau akidah. Ilmu Kalam, misalnya, lebih menekankan aspek pembenaran dan pembelaan akidah secara sepihak, sehingga coraknya bersifat doktrinal, dogmatik, tegas, tegar, keras, agresif, defensif, dan apologis. Ilmu Kalam digulirkan untuk menetapkan persepsi terhadap ideologi-ideologi religius melalui dalil-dalil ideologis berdasarkan asas-asas rasionalisme demonstratif, sehingga memungkinkan untuk memahami, memunculkan, dan membela ideologi Islam. ${ }^{22} \mathrm{Hal}$ ini tidak terlepas dari tujuan pengajaran Ilmu Kalam itu sendiri, yaitu menanamkan paham keagamaan yang benar, sebagaimana diajarkan di madrasah-madrasah dan pesantrenpesantren. Kalaupun terdapat sebagian kalangan yang berupaya untuk "mengkaji dan mengembangkannya" secara ilmiah, aktivitas intelekutalisme tentang hal itu biasanya tidak jauh dari semangat apologetik-legitimatik dan menyebarluaskan paham atau mazhab

${ }^{20}$ Al-Jabiri, Post-Tradisionalism, h. xxxix, 59-65.

${ }^{21}$ M. Amin Abdullah, Falsafah Kalam di Era Posmodernisme (Yogyakarta: Pustaka Pelajar, 1995), h. 79-94; Abdullah, Islamic Studies, h. 154.

${ }^{22}$ Hasan Hanafi, Islamologi dari Teologi Statis ke Anarkhis, terj. Miftah Faqih (Yogyakarta: LKiS, 1992), h. 1. 
tertentu, sebagaimana yang terwujud melalui tradisi syara $\underline{h}$ (penjelasan-penjelasan) dan tradisi hâSyi'ah (komentar-komentar). Para sarjana Muslim yang hidup pada paruh akhir abad pertengahan mempelajari seluruh bidang pengetahuan melalui komentator-komentator yang ada ketika itu. Dalam perkembangannya, tradisi intelektualisme Islam berpola syara $\underline{h}$ dan $\underline{h} \hat{a s y i a h ~ i t u ~ m e l a h i r k a n ~ p a r a ~ s a r j a n a ~ M u s l i m ~ b e r t i p i k a l ~ k o m e n t a t o r ~ d a n ~ s e k a l i g u s ~ s e b a g a i ~}$ kolektor karya-karya komenter yang ada. Mereka secara garis besar terbagi kepada dua tipe, yaitu tipe pemikir yang komprehensif, dan tipe pemikir yang kurang atau tidak komprehensif. Pengkajian keilmuan seperti itu hanya memunculkan para sarjana bertipe ensiklopedik dan mereka sendiri tidak pernah menyumbangkan gagasan-gagasan baru.

Fenomena ini menunjukkan bahwa kegiatan intelektual tidak dipandang sebagai suatu usaha yang bertujuan untuk mencari dan menemukan hal-hal yang baru sebagai suatu dorongan kreatif untuk menggapai pikiran-pikiran yang belum diketahui, akan tetapi lebih dipandang sebagai penyerapan secara pasif terhadap pengetahuan yang telah ada. Ringkasnya, kegiatan keilmuan berpola syarah dan $\underline{h} \hat{a} s y i a h$ ini, secara substantif tidak memberikan sumbangsih apa pun terhadap pengembangan keilmuan atau pemikiran Islam.

Dalam perwujudannya, merujuk kepada hasil penelitian Aziz al-Azmeh dan Martin van Bruinessen, ${ }^{23}$ jenis karangan ulama dan ilmuan Islam abad pertengahan yang didominasi oleh tradisi syarah dan $\underline{h}$ âsyiah itu pada umumnya dapat dipastikan termasuk dalam salah satu jenis dari delapan jenis kegiatan keilmuan sebagai berikut, yaitu melengkapi teks yang belum lengkap; memperbaiki teks yang mengandung kesalahan; menjelaskan atau menafsirkan teks yang samar; meringkas (ikhtisar) dari teks yang panjang-panjang; menggabungkan teks yang terpisah-pisah tetapi saling berkaitan (namun tanpa ada usaha yang sistematis); menata tulisan yang masih simpang siur; mengembalikan kesimpulan dari premis-premis yang sudah diketahui; dan menerjemahkan ke dalam bahasa lokal.

Model kegiatan ilmiah tersebut berhasil melahirkan karya-karya ilmiah dalam bentuk manuskrip-manuskrip atau dicetak dalam bentuk "kitab-kitab kuning" (al-kutub al-safra'), namun secara substantif "upaya pengembangan keilmuan keislaman" ketika itu cenderung berjalan di tempat untuk tidak mengatakan mengalami stagnasi atau proses pembakuan/pembekuan keilmuan. Dalam pada itu, transmisinya melalui lembaga-lembaga pendidikan Islam tradisional, seperti halaqah, zâwiyah, khandaqah, meunasah, surau, pesantren, madrasah dan universitas (jamiah), pun sering dipengaruhi oleh dan (atau) berorientasi kepada pentradisian dan penyebarluasan mazhab tertentu. Tujuannya tidak lebih dari upaya pentransmissian secara turun-temurun dan upaya mempertahankan khazanah intelektualisme Islam klasik yang sudah terpatri dengan kokoh dalam tradisi turâts tersebut apa adanya. Sedangkan kritik dan mempertanyakan ulang mana aspek normativitas dan mana aspek historisitasnya guna pengembangan temuan-temuan keilmuan

${ }^{23}$ Sebagaimana dikutip dalam Martin van Bruinessen, Kitab Kuning: Pesantren dan Tarekat (Bandung: Mizan, 1995), h. 31. 
terhadapnya, dipandang oleh mayoritas umat sebagai sesuatu yang tidak mungkin dilakukan oleh karena hal itu ditengarai dapat menggoyahkan sendi-sendi keilmuan yang dipandang sudah mapan dan bahkan sakral.

Di zaman modern, muncul upaya untuk mereaktualisasi khazanah intelektualisme Islam klasik itu sebagaimana yang diusung oleh gerakan tradisionalisme Islam. Di samping menggunakan pendekatan tekstual, tradisionalisme Islam sebagaimana yang dipelopori oleh S.H. Nasr, misalnya, juga mulai menggunakan pendekatan filosofis sekalipun hal itu lebih ia tekankan pada aspek iluminatif. Yaitu, suatu usaha yang ingin menggabungkan kemampuan akal dan rasa dalam upaya mencapai keutuhan pemahaman terhadap realitas. Akan tetapi, secara keseluruhan, model pendekatan filosofis-iluminatif itu kurang begitu simpati terhadap pendekatan sosial dan pendekatan sejarah terhadap realitas keberagamaan manusia, ${ }^{24}$ sehingga kontribusinya dalam melahirkan ilmu-ilmu keislaman dalam konteks kekinian tidak banyak memberikan sumbangsih, terutama berkenaan dengan persoalanpersoalan kehidupan iptek, sosial, politik, ekonomi, dan lain-lain. Sekalipun demikian, upaya reaktualisasi khazanah intelektualisme Islam klasik sebagaimana yang diusung oleh gerakan tradisionalisme Islam itu tampaknya lebih ditujukan untuk menggali solusi bagi kegersangan spiritualisme keagamaan dan keterpecahan kepribadian manusia di zaman modern yang didominasi oleh pola pikir sekularisme-matarialistik.

\section{Pola Interaksi Paradigma Kalam, Fikih, Falsafah dan Tasawuf}

Sekalipun keempat disiplin ini memperoleh inspirasi awal dari al-Qur'an dan hadis, pola pikir konsensus (ijmâ) dan logika bahasa Arab (pola pikir qiyâs), tidak berarti hal itu dapat menyatukan visi keilmuan di antara mereka. Sekalipun berada dalam satu rumpun ilmu-ilmu keislaman, dalam praktiknya keempat disiplin itu hampir-hampir tidak mau akur. Bahkan, klaim supremasi interpretasi yang dimiliki oleh satu disiplin ilmu atas disiplin ilmu yang lainnya sering kali terjadi dan bahkan tidak jarang berpola persekutuan secara kolaboratif.

Secara umum, di satu pihak pola interaksinya berwujud persekutuan antara pola pikir Kalam dengan pola pikir Fikih. Persekutuan secara kolaboratif antara keduanya samasama bermuara pada penekanan finalitas, ketertutupan (closed system), ketetapan (stationary), dan eksklusivitas pemikiran Islam. Di pihak lain, pola interaksinya berbentuk persekutuan antara pola pikir tasawuf dengan falsafah di mana keduanya sama-sama menekankan sifat ketidakfinalan suatu pemikiran (open ended), keterbukaan (open system), kesedang berprosesan (on going process), dan inklusivitas pemikiran Islam. Kolaborasi pola pikir tasawuf dan falsafah menitikberatkan dimensi kedalaman, psikologis, transhistorikalitas-esoterikspritualitas yang tidak harus terbelenggu dan terjebak oleh keberagamaan secara eksoteris-

${ }^{24}$ Seyyed Hossein Nasr, Knowledge and the Sacred (Lahore: Suhail Acakemy, 1988), h. 75-95. 
organisatoris. Filsafat dan tafsir bercorak esoterik-sufistik pernah dipandang sinis oleh para ulama yang menggeluti dan mengajarkan Ilmu Fikih/Ushul Fikih dan Ilmu Kalam, baik dalam tradisi Islam Sunni maupun Islam Syi'ah. Bahkan, pemangku antarilmu keislaman tidak jarang saling menafikan. ${ }^{25}$ Pertentangan antara kelompok-kelompok itu tidak terlepas dari perbedaan metode yang mereka gunakan dalam memaknai teks-teks keagamaan. Para filosof Muslim dan juga para sufi pada umumnya berpegang pada model pemaknaan secara allegoris atau ta ' wîl terhadap ayat-ayat al-Qur'an dan teks-teks hadis. Sedangkan kelompokfuqahâ' dan kalangan mutakallim pada umumnya berpegang pada makna literaltekstualis.

Perbedaan metode ini pada gilirannya berdampak terhadap munculnya sikap saling reaktif bercorak fanatisme mazhab. Dalam pandangan kelompok nonliteralis (kalangan filosof dan sufi), kelompok literalis (fuqahâ' dan mutakallim) terlalu memaksakan keunggulan otoritas teks-teks kewahyuan atas penggunaan nalar manusia. Sebaliknya, dalam pandangan kelompok literalis, kelompok nonliteralis memperlakukan teks-teks kewahyuan secara tidak lazim, sulit dicerna, bid'ah, sesat, dan bahkan kufur. ${ }^{26}$

\section{Pengaruh Pola Pikir Tekstual-Bayânî/Irfânî terhadap Pembentukan Corak Pemahaman, Sikap, dan Perilaku Keberagamaan Umat}

Dalam perkembangannya, keragaman pola kolaborasi sistem dan pola pikir dalam tradisi keilmuan Islam klasik pada gilirannya berdampak terhadap terbentuknya institusiinstitusi keagamaan yang saling bergesekan atau berhadap-hadapan antara satu dengan yang lain. Bahkan, secara hegemonik antarpenganut epistemologi masing-masing tidak jarang saling mengkafirkan, saling memurtadkan, dan saling mensekulerkan. Fenomena tersebut dapat diperhatikan dalam sejarah pemikiran Islam klasik yang tumbuh dan berkembang tergantung pada konteks dan cuaca pergumulan sosial-politik yang sedang dihadapi oleh umat Islam pada suatu era dan wilayah.

Secara teoretis, pendekatan tekstual-bayânî cenderung menggiring seseorang kepada pola pikir keagamaan yang bersifat absolut, yaitu klaim kebenaran terhadap pemikirannya sendiri secara mutlak. Model pemikiran ini selalu mengambil jarak sejauh mungkin dari campur tangan dan intervensi orang lain. Pola pikir model ini sangat kaku dan tidak mengenal kompromi. Model pemikiran ini mudah terjebak dalam pensakralan pemikiran keagamaan (taqdîs al-afkâr al-dînî). Pola pikir model ini melupakan dimensi ruang dan waktu kesejarahan (târîkhiyyât) dari pemikiran keagamaan.

Selanjutnya, para pemangku model pemikiran seperti ini pada gilirannya sangat

${ }^{25}$ Abdullah, Islamic Studies, h.154; Hanafi, Islamologi, h. 4.

${ }^{26}$ Muhammad Taqi' Misbah Yazdi, Philosophical Introduction: An Introduction to Contemporary Islamic Philosophy (New York: University of Binghamton, 1999), h. xv-xvi. 
rentan tergiring kepada sikap dan perilaku fanatisme buta (taqlîd), cenderung menyerang pola pikir dan keimanan yang dimiliki oleh orang lain (al-'uqûl al-mutanâfisah), dan sulit diajak dialog bertukar pikiran secara jernih dengan kesediaan untuk melakukan proses take and give. Para penganut pola pikir keagamaan yang bercorak absolut teguh dalam bersikap, tidak luwes dalam berkomunikasi dan bergaul dengan sesamanya. Pemahaman teks-teks wahyu secara tekstual (harfiyyah) menjadi stumbling block untuk melakukan kajian sosial dan budaya lebih lanjut terhadap perilaku keagamaan. ${ }^{27}$

Selanjutnya, dalam kaitannya dengan hubungan antarumat beragama, oleh karena sifatnya yang kaku dan rigid, pola pikir tekstual-bayânî, jika tidak berhati-hati, dapat mengarah pada pembentukan sikap eksklusif-absolut dalam beragama, terlebih-lebih ketika berhadapan dengan teks-teks keagamaan yang dimiliki oleh komunitas, kultur, bangsa, dan masyarakat yang beragama lain. Dalam berhadapan dengan komunitas yang berlainan agama, corak argumentasi penganut agama yang memiliki pola pikir tekstual-bayânî biasanya mengambil sikap mental yang bersifat dogmatik, defensif, opologetik, dan polemik, sebagaimana yang biasa digunakan oleh para ahli Fikih (fuqahâ'), para ahli Kalam (mutakallimûn), para ahli tata bahasa Arab (nuhâ).

Dalam skala yang lebih luas, khususnya ketika berhadapan dengan perubahan dan perkembangan zaman modern, pola pikir deduktif-tekstual-skriptual-bayânî sebagaimana yang biasanya mewarnai pola pikir kalam dan Fikih akan mengalami kesulitan yang luar biasa. Dominasi pola pikir ini menjadikan sistem epistemologi ilmu-ilmu keislaman klasik kurang begitu peduli terhadap isu-isu keagamaan yang bersifat kontekstual, aktual, dan faktual. Kalau pun dipaksakan, sudut pandangnya kurang tajam dalam melihat dan mencermati fenomena alam, budaya, dan sosial kemasyarakatan yang selalu berubah dan berkembang dengan sangat cepat dan massif. ${ }^{28}$ Oleh karena itu, pengembangan metodologi ilmu-ilmu keislaman klasik sangat dimungkinkan dan harus dilakukan agar tidak mengalami penyempitan horizon cara pandang terhadap realitas keberagamaan manusia di dunia kekinian yang semakin kompleks dan global.

\section{Kritik terhadap Pola Pikir Tekstual-Bayânî dan 'irfânî}

Pola pikir model tekstual-bayânî berikut sikap dan perilaku keberagamaan secara eksklusif mungkin bagus dan terpuji untuk wilayah keagamaan yang bersifat homogen. Dalam struktur masyarakat yang homogen itu, pola pikir, sikap, dan perilaku keagamaan mereka selalu memandang bahwa ajaran agama seluruhnya bersifat tauqify. Unsur wahyu lebih dikedepankan dari pada akal. Teks lah yang dianggap sebagai satu-satunya otoritas yang memiliki kekuasaan secara hegemonik. Sedangkan akal dalam hal ini sifatnya pasif

${ }^{27}$ Abdullah, Islamic Studies, h. 82-84.

${ }^{28}$ Hasan Hanafi, Dirâsât Islâmiyah (Kairo: Maktabah al-Anjilu al-Misriyyah, t.t.), h. 393415. 
berfungsi sebagai abdi dari teks, akal tidak memiliki kreativitas atau kebebasan intelektual sama-sekali. Perananakal pikiran dalam memahami dan menafsirkan hal-hal yang terkait dengan soal keberagamaan manusia sangat terbatas. Fungsi dan peranan akal diletakkan pada posisi pengukuhan dan pembenaran terhadap otoritas teks. Bahkan, hal-hal yang dicurigai sebagai produk akal cepat-cepat dituduh sebagai bid'ah yang sesat menyesatkan bahkan dapat menggiring seseorang ke neraka. Artinya, pendekatan tekstual-bayânî lebih menekankan dimensi kepatuhan secara otalitas ( $t a^{\prime} a b b d u d y$ ) daripada dimensi rasionalitas (ta'aqquly).

Berkaitan dengan persoalan ini, secara epistemologis, dapat pula dikemukakan kritikan Ibn Hazm al-Andalusi yang sering digolongkan oleh para penulis sebagai tokoh Fikih yang literalis (zhâhirî $)^{29}$ itu. Ia tidak saja menyerang sikap bertaklid ${ }^{30}$ kepada mazhab-mazhab Fikih, akan tetapi juga melontarkan kritikannya terhadap prinsip-prinsip epistemologi bayânî. Metode qiyâs, menurut Ibn Hazm hanya berlaku dan dibenarkan dalam konteks satuan unsur-unsur yang punya jenis yang sama dan sepadan. Artinya, qiyâs dapat diterima dalam kategori yang mempertemukan keseluruhan individu atau partikularitas dalam satu karakter dan sifat yang sama. Sebaliknya, jika dipakai dalam satuan-satuan atau individu-individu yang berasal dari kategori yang berbeda atau tidak dipertemukan oleh satu karakter wujud yang sama, qiyâs tidak dapat diterima atau tidak berlaku.

Dalam ilmu Fikih, misalnya, fuqahâ' menganalogikan antara satu wujud dengan wujud lainnya yang berbeda jenis dan karakter satu sama lain, sementara yang dikedepankan dalam hal ini hanyalah aspek keserupaan atau kemiripan di antara keduanya. Padahal,

\footnotetext{
${ }^{29}$ Namun, pandangan seperti itu, dalam hemat al-Jabiri merupakan sebuah kesesatan yang disengaja atau tidak disengaja. Bagi al-Jabiri, Ibn Hazm adalah seorang tokoh besar perintis munculnya satu babak baru dalam sejarah tradisi pemikiran Islam. Literalisme yang dikedepankan Ibn Hazm adalah literalisme yang kritis dan berdimensi epistemologis. Disebut kritis, oleh karena Ibn Hazm memberontak terhadap mazhab-mazhab fikih resmi, terlebih-lebih terhadap otoritas negara yang melegitimasi satu mazhab fikih tertentu. Selanjutnya, disebut berdimensi epistemologis, oleh karena argumentasinya bertitik tolak dari pandangan yang integral dan utuh tentang akidah dan syariah dengan mengadopsi logika, ilmu-ilmu alam, dan filsafat. Jadi, literalismenya bukan literalisme tekstual yang mentaklid kepada orang lain. Al-Jabiri, PostTradisionalisme, h. 119-121.

${ }^{30}$ Menurutnya, siapa pun tidak diperkenankan untuk bertaklid kepada seseorang, baik terhadap faqih yang masih hidup maupun yang sudah wafat. Setiap orang berhak melakukan ijtihad sesuai dengan kemampuannya. Mereka yang bukan berkategori ulama, berkewajiban bertanya kepada para ulama yang lebih tahu tentang persoalan-persoalan agama. Selanjutnya, para ulama harus menyampaikan ajaran-ajaran agama berserta dalil-dalilnya kepada si penanya sehingga bisa mengetahui dengan pasti objek yang ditanyakannya itu. Dengan cara inilah sang penanya telah memikul suatu tanggung jawab dan sekaligus telah melakukan ijtihad berdasarkan kemampuannya. Artinya, sekalipun tidak sampai pada tataran mujtahid mutlak, Ibn Hazm setidaknya telah membuka ruang bagi seseorang untuk cerdas (ittiba') dan bertanggung jawab dalam beragama. Dalam salah satu pernyataan, Ibn Hazm menegaskan, "Ketahuilah, siapapun yang bertaklid kepada seorang sahabat, tokoh kharismatik, seorang raja, atau bertaklid kepada Abu Hanifah, al-Syafi `i, Sufyan al-Tsauri, al-Auza 'i, Ahmad ibn Hanbal, atau Daud al-Zahiri, mereka semuanya tidak bertanggung jawab atas apa yang dilakukan oleh orang-orang yang bertaklid itu". Ibid.
} 
menurut Ibn Hazm, unsur keserupaan atau kemiripan di antara wujud tidaklah mengharuskan adanya persamaan dalam hukum-hukumnya. Sebab, seandainya dibenarkan menerima hal seperti itu, konsekuensinya sesuatu yang dipersamakan itu akan memiliki status hukum yang sama. Di sisi lain, kalaupun terdapat argumen yang menyatakan bahwa "suatu bentuk kemiripan yang lebih besar dapat dijadikan sebagai dasar atau alasan ( 'illah) bagi lahirnya suatu ketentuan hukum, sebagaimana yang diyakini oleh mayoritas fuqahâ', dalam hemat Ibn Hazm hal itu hanyalah rekaan semata (zhan). Sementara bagi Ibn Hazm, persoalan agama haruslah didasarkan atas suatu kepastian, bukan dugaan, dan kepastian itu hanya dapat diperoleh dari teks agama (wahyu). Selanjutnya, berkaitan dengan metode qiyâs yang lazim digunakan di bidang ilmu kalam oleh para mutakallim, Ibn Hazm juga menilainya tidak sah. Sebab, hakikat wujud dunia riil atau tampak oleh panca indera (alsyâhid) yang bersifat insaniah berbeda dengan dunia abstrak (al-ghaib) yang bersifat ilahiah. Bagaimana mungkin wujud sesuatu dianalogikan dengan wujud sesuatu lainnya padahal di antara keduanya terdapat perbedaan "dunia" yang sangat tajam. Dunia manusia adalah dunia yang penuh dengan kekurangan dan kerusakan, sedangkan dunia ilahiah adalah dunia penuh kesempurnaan dan kekekalan. Atas dasar pemikiran ini, Ibn Hazm menyatakan bahwa metode qiyâs dalam Ilmu Fikih atau Ilmu Kalam merupakan metode yang tidak absah.

Bila merujuk pada diskursus wacana kontemporer sebagaimana yang dikaji oleh pendekatan hermeneutik, ternyata beragam model pemaknaan terhadap teks sangat dimungkinkan, tidak semata-mata melalui pola pikir bayânî. Secara hermeneutik, makna teks tidak semata-mata ditentukan oleh pengarang teks, akan tetapi tidak bisa dilepaskan dari bahasa manusia dan teks itu sendiri. Jika menggunakan pendekatan ini dalam hal pemahaman terhadap perintah-perintah Tuhan (divine instructions), jelas bahwa keterkaitan antara pengarang (Tuhan), teks (kitâbah, qawliyah), dan pembaca tidak dapat dipisahkan. Di sini lah mulai muncul persoalan oleh karena pesan-pesan ilahiah yang bersifat mutlak disampaikan melalui simbol-simbol atau teks kebahasaan tertentu yang memerlukan bantuan dan dukungan asosiasi-asosiasi tertentu, gambaran-gambaran, emosi para pengguna dan pendengar bahasa yang berbeda-beda dan bisa saja berubah dari waktu ke waktu. Artinya, bahasa memiliki realitas objektifnya sendiri, maknanya tidak dapat ditentukan secara efektif dan sepihak oleh pengarangnya maupun pembacanya. Begitu sebuah teks dilahirkan, ia memiliki dunia kehidupan, hak-hak, dan integritasnya sendiri. Sedangkan teks yang tidak mampu membebaskan diri dari tekanan kekuasaan pengarangnya atau tidak dapat memberi inspirasi segar bagi para pembacanya (reader) atau tidak mampu merangsang dengan berbagai nuansa makna yang terkandung di dalamnya akan mengalami nasib yang menjemukan, mudah ditebak, kaku, dan tertutup. Sedangkan dominasi yang berlebih pada salah satu pihak akan menyebabkan kebuntuan intelektual. Hanya teks yang mampu menjaga keterbukaannya yang akan tetap hidup, relevan, dan memiliki resonansi yang kuat.

Paradigma 'irfânî, karena sifatnya "sebagai pengetahuan yang diperoleh (al- $\underline{h} u d h u r \hat{\imath}$ ladûnî)" sering dipandang sebagai penyebab terhambatnya laju daya kreativitas dalam 
menciptakan ilmu pengetahuan dan teknologi. Sebab, dalam hal ini posisi manusia lebih cenderung bersifat pasif dan nrimo daripada kreatif dan positif, ${ }^{31}$ menunggu munculnya ilham secara spritualistik. Kemudian daripada itu, jika metode textual-bayânî lebih menonjolkan dimensi materialistik-eksoterik dari berbagai simbol dan kategorisasi suatu objek, maka metode irfânî lebih menonjolkan spritualitas-esoterik. Dampaknya, pengetahuan 'irfânî sangat kuat kecenderungannya mengantarkan pola pikir dan tolok ukur validasinya secara empati, simpatik, inklusif, intersubjektif, toleran, dan pluralistik (unity in difference) ${ }^{32}$ daripada bersifat objektif-rasionalistik atau positivistik.

Atas dasar itu, pola pikir tekstual-bayânî dan irfâni harus mampu memahami, berdialog, dan mengambil manfaat sisi-sisi fundamental yang dimiliki oleh pola pikir burhânî (optimalisasi fungsi akal dan observasi/eksperimentasi) secara integral-interkonektif sesuai dengan ranah kajiannya masing-masing, guna menggali esensi ajaran atau doktrin keagamaan, terutama bila dihadapkan dengan berbagai persoalan dalam kehidupan manusia dengan konteks yang beragam, sehingga kesimpulan atau solusi yang ditawarkannya tentang suatu persoalan dapat lebih arif, bijaksana, kontekstual, dan tepat guna. ${ }^{33}$

\section{Penutup}

Struktur paradigmatik ilmu-ilmu keislaman zaman klasik, mencakup bidang Ilmu Kalam, Ilmu Fikih/Ushul Fikih, dan Ilmu Tasawuf, sebagaimana yang tersebar di dunia Muslim Sunni berparadigma tekstual-bayânî dan irfânî. Postulat-postulatnya didasarkan atas informasi kewahyuansebagaimana yang termaktub di dalam al-Qur'an dan hadis. Secara ontologis, objek-objek kajiannya terbatas pada persoalan-persoalan normativitas keislaman, mencakup akidah, syariah, dan akhlak. Secara epistemologis, otoritas teks dan corak penafsiran terhadapnya secara analogis (qiyâs) dan konsensus (ijmấ) sangat dominan guna menjelaskan, menguraikan, dan melegitimasi informasi yang diperoleh dari teks daripada penalaran akal. Secara aksiologis, ilmu-ilmu keislaman klasik itu lebih berorientasi pada upaya penuntunan dan pembinaan karakter dan moral-spiritual (ukhrawi oriented) keagamaan secara islami, di samping mempertahankan ajaran-ajaran dan doktrin-doktrin keislaman itu secara dogmatik-apologetik. Sedangkan pola pikir burhânî, sebagaimana yang dimiliki oleh bidang Ilmu Falsafah, tidak begitu berkembang di dunia Islam, dan bahkan cenderung disisihkan, sehingga ruang kreativitas dan inovasi intelektual secara bebas tidak dapat dilahirkan. Ia takluk di bawah bayang-bayang otoritas teks keagamaan dan pola pikir ulama salaf dalam bentuk ijmấ dan analogi (qiyâs). Akibatnya,

${ }^{31}$ Rahman, Islam, h. 279

${ }^{32}$ Abdullah, Islamic Studies, h. 380-381. Bandingkan, Hasan Askari dan Jon Avery, Towards A Spritual Humanism: A Muslim-Humanist Dialogue (Ledds: Seven Mirrors Publishing House Limited, 1991), h. 69-90.

${ }^{33}$ Abdullah, Islamic Studies, h. 203-204. 
pendekatan dan pemahaman terhadap persoalan-persoalan baru yang muncul dalam kehidupan ummat zaman kekinian menjadi sangat kaku dan eksklusif. Bahkan, hal itu pada gilirannya turut pula membentuk worldview sebagian besar umat Islam dalam meyongsong dan menghadapi tantangan modernitas dan globalisasi, mereka bersikap dan berperilaku stagnan, tidak kreatif, fanatik dan cenderung emosional-anarkis.

\section{Pustaka Acuan}

Abdullah, M. Amin. Falsafah Kalam di Era Postmodernisme. Yogyakarta: Pustaka Pelajar, 1995.

Abdullah, M. Amin. Islamic Studies di Perguruan Tinggi. Yogyakarta: Pustaka Pelajar, 2006.

Askari, Hasan dan John Avery. Towards A Spritual Humanism: A Muslim-Humanist Dialogue. Ledds: Seven Mirrors Publishing House Limited, 1991.

Arkoun, Mohammed. Al-Islâm: al-Akhlâq wa al-Siyâsah. Beirut: Markaz al-Inma' alQaum, 1990.

Babbie, Earl. The Practice of Social Research. Belmont: Wadsworth, 200.

Bruinessen, Martin van. Kitab Kuning: Pesantren dan Tarekat. Bandung: Penerbit Mizan, 1995.Burts, Arthur. The Metaphysical Foundation of Modern Science. New York: Doubleday Anchor Books, 1954.

Faqih, Mansur. "Teologi Kaum Tertindas," dalam Ahmad Suedy (ed.) Spritualitas Baru: Agama dan Aspirasi Rakyat. Yogyakarta: Institut Dian/Interfidei, 1994.

Al-Faruqi, Ismail Raji. "Islamization of Knowledge: Problems, Principles and Prospective," dalam The International Institute of Islamic Thought, Islam: Source and Purpose of Knowledge. Herndon, Virginia, USA: IIIT, 1988.

Hamilton, Edith dan Cairns, Huntington (ed.) Plato: The Collected Dialogues. USA: Princeton University Press, 1961.

Hanafi, Hasan. Dirâsat Islâmiyah. Kairo: Maktabah al-Anjilu al-Misriyyah, t.t.

Hanafi, Hasan. Islamologi dari Teologi Statis ke Anarkhis. Penerjemah Miftah Faqih. Yogyakarta: LKiS, 1992.

Al-Jabiri, M. Abed. Takwîn al-Aq al-Arabî. Beirut: Markaz Dirâsât al-Wihdah al- `Arabiyyah, 1989.

Al-Jabiri, M. Abed. Post-Tradisionalisme Islam. Yogyakarta: LKiS, 2000.

Genequand, Charles. "Metaphysics," dalam Seyyed Hossein Nasr. History of Islamic Philosophy. London and New York: Routledge, 1996.

Kartanegara, Mulyadhi. Nalar Religius: Memahami Hakikat Tuhan, Alam, dan Manusia. Jakarta: Erlangga, 2007.

Kartanegara, Mulyadhi. Mengislamkan Nalar: Sebuah Respons terhadap Modernitas. Jakarta: Penerbit Erlangga, 2007. 
Kuhn, Thomas. The Structures of Scientific Revolution. Chicago: The University of Chicago Press, 1970.

Madjid, Nurcholish. Islam Doktrin dan Peradaban. Jakarta: Paramadina, 2000.

Mautner, T. (ed.), Dictionary of Philosophy. London: Pinguin Books, 1996.

Nasr, Seyyed Hossein. Knowledge and the Sacred. Lahore: Suhail Academy, 1988.

Nasr, Seyyed Hossein. "Filsafat Hikmah Suhrawardi," dalam Jurnal Ulum al-Qur'an, Edisi ke-3/VII/1997.

Nurgiantoro, Burhan. Teori Pengkajian Fiksi. Yogyakarta: Gadjah Mada University Press, 1995.

Philips, Bernard S. Social Research, Strategy and Tactics. New York: Macmillan, 1971.

Rahman, Fazlur. Islam and Modernity: Transformation of an Intellectual Tradition. Chicago and London: The University of Chicago Press, 1982.

Rahman, Fazlur. Islam. Chicago: The University of Chicago Press, 1979.

Rahman, Fazlur. Islam, terj. Ahsin Muhammad. Bandung: Penerbit Pustaka, 1997.

Ess, Josep van. "The Logical Structure of Islamic Theology”, dalam Issa J Boullata, (ed.), Anthology of Islamic Studies. Montreal Canada: McGill and Indonesia IAIN Development Project, 1992.

Yazdi, M.T. Misbah. Philosophical Introduction: An Introduction to Contemporary Islamic Philosophy. New York: University of Binghamton, 1999. 